Type of the Paper (Article, Review, Communication, etc.)

\title{
A Study on the Risk Management Strategy for Military Installations Project of Yongsan Relocation Plan using Structural Equation Model
}

\author{
Hobin Yoon ${ }^{1}$, Chansik Lee ${ }^{2 *}$ \\ Department of Architectural Engineering, Incheon National University, Incheon 22012, Korea; \\ hbyoon@samoocm.com (Y.H.B.); cslee@incheon.ac.kr (L.C.S.) \\ * Correspondence: cslee@incheon.ac.kr; Tel.: +82-32-835-4657
}

\begin{abstract}
Some of the recent large-scale national projects in South Korea are delayed or suspended due to belated responses to risk occurring on site. Currently, the Far East District (FED) project is being implemented to relocate the US Army bases from Yongsan to Pyeongtaek. Because of lack of experience and understanding about the characteristics of such a project, the deadline of taking over to the US Army Korea has been missed. This study identifies problems of each participant in the Yongsan Relocation Plan (YRP) of the US Army Korea with respect to construction project management and establishes a risk management strategy reflecting characteristics of FED project. To derive significant risk factors influencing YRP, various field data like weekly and monthly reports and other reports on construction condition are analyzed, and experts' advices are collected and a survey is conducted. Mediators and latent variables are ultimately obtained. Furthermore, a structural equation model is used to both analyze and evaluate complex causal relations among many variables of YRP. The impact of risk factors on the schedule, quality and cost of the project is analyzed. In particular, the case of Site A is examined to see how the project is affected by those risk factors.
\end{abstract}

Keywords: Military Installations Project, Risk Factor, Structural Equation Model

\section{Introduction}

\subsection{Background and goal of study}

Many relocation plans of military installations are often delayed because of the conflict of interest between stakeholders and institutional ambiguity [1]. Such a delay is frequently attri butable to domestic construction companies which pay much attention to cost and process ma nagement but tend to neglect risk management. Accordingly, legal disputes between clients an d project managers often occur concerning work scope and responsibility for costs [2]. The Yo ngsan Relocation Plan (YRP) is a joint international project between the South Korean Ministr $y$ of National Defence and the US Army Korea. The total cost of this project is estimated to $b$ e 15.9 trillion KRW, and 129 US military bases will be relocated and integrated into 49 bases including administrative, medical and religious facilities (A press release issued in July, 2017). According to the sources of funds, YRP consists of an endowment \& concession project $\left(\mathrm{LH}^{1}\right.$ project) and a special account project (MURO'2 project). The E-MOU (2015) ${ }^{3}$ specifies that ever $\mathrm{y}$ decision should be made under the agreement and approval of $\mathrm{DCA}^{4}$ of South Korea and $\mathrm{t}$

\footnotetext{
${ }^{1}$ Korea Land and Housing Corporation

${ }^{2}$ MND USFK Relocation Office

${ }^{3}$ Engineering Memorandum of Understanding, which contains every issue concerning techniques of the project under the agreement between South Korea and the US.

${ }^{4}$ Design Construction Agency
} 
he US and the project should be implemented in accordance with the design and construction standards of FED (Far East District) ${ }^{5}$. Many domestic and overseas contractors, designers, con structors, CM and CS participate in YRP. The construction was going to be completed by 201 5 and about 3/4 of the US troops in South Korea were going to move to the Pyeongtaek garri son by 2016. However, as YRP was implemented by focusing on reducing the period and sav ing costs, the risk management turned out be fragile and thus the completion of YRP is being delayed.

As of now, domestic companies participate in the project along with some global countri es, the FED project is temporarily suspended or delayed for many reasons including the failur e of risk management. Besides, as risk factors, which had not been considered, emerged later, some constructed parts have been dismantled and reconstructed. YRP requires the understand ing of FED project and the expertise in FED specifications. This needs to be accompanied by professional management activities. Moreover, the project is implemented by various participa nts. Accordingly, it is important to management risk factors originating from complex relation ship of interests. YRP requires a different approach from the conventional methods of project management. Delay factors have been focused to identify problems in implementing YRP. Ho wever, risk factors concerning construction project management have hardly been analyzed.

This study examined the process of FED project, which was applied to YRP, and analyze $\mathrm{d}$ the problems of participants of YRP including the client on the South Korean side, that on the US side, constructors, designers and construction project managers. Risk factors, which we re to be considered for FED project, were examined with respect to construction project mana gement. A structural equation model was utilized to quantitatively analyze the interaction am ong schedule, quality and cost. Finally, a risk management strategy for such military installati ons relocation projects is proposed.

1.2. Scope and methodology of study

This study attempted to analyze direct and indirect risk factors of YRP and propose a risk management strategy reflecting characteristics of FED project. Among various types of facilities included in YRP, this study focused on Site A, which was irrelevant military secrets of the US Army, and confined the scope of analysis to works ordered by the South Korean client. Risk factors were identified by using the Delphi method, and a structural equation model was applied for quantitatively examining whether those factors directly or indirectly had a significant effect on schedule, quality and cost. Objectives of construction project management were proposed to facilitate an on-site response to problems of FED project. Figure 1 schematically presents the procedure and method of this study.

1) Domestic and overseas research papers were surveyed and analyzed. Field data like $\mathrm{NCR}^{6}$ and $\mathrm{MaDTaG}^{7}$ and regular reports were used to identify problems and characteristics of each participants of YRP.

2) Based on literature review and field survey, 35 risk factors, which were commonly applied to all the sites of YRP, were identified for main projects. 19 risk factors for each participant were obtained through the interview with field managers.

3) The Delphi technique was used for field managers of YRP in order to derive final risk factors. A structural equation model was developed and hypotheses were set.

4) The structural equation model was utilized to quantitatively analyze the correlation of schedule, quality and cost. The hypotheses of the structural equation model were verified by measuring reliability and analyzing validity. Directly or indirectly significant hypotheses were adopted.

5) Objectives of construction project management, which were applicable to each site of YRP, were established and actually applied to Site A. A risk management strategy was established and proposed.

\footnotetext{
5 The US Army Corps of Engineers Far East District

${ }^{6}$ Non-Conformance Report

7 Master Deficiency Tracking Log
} 


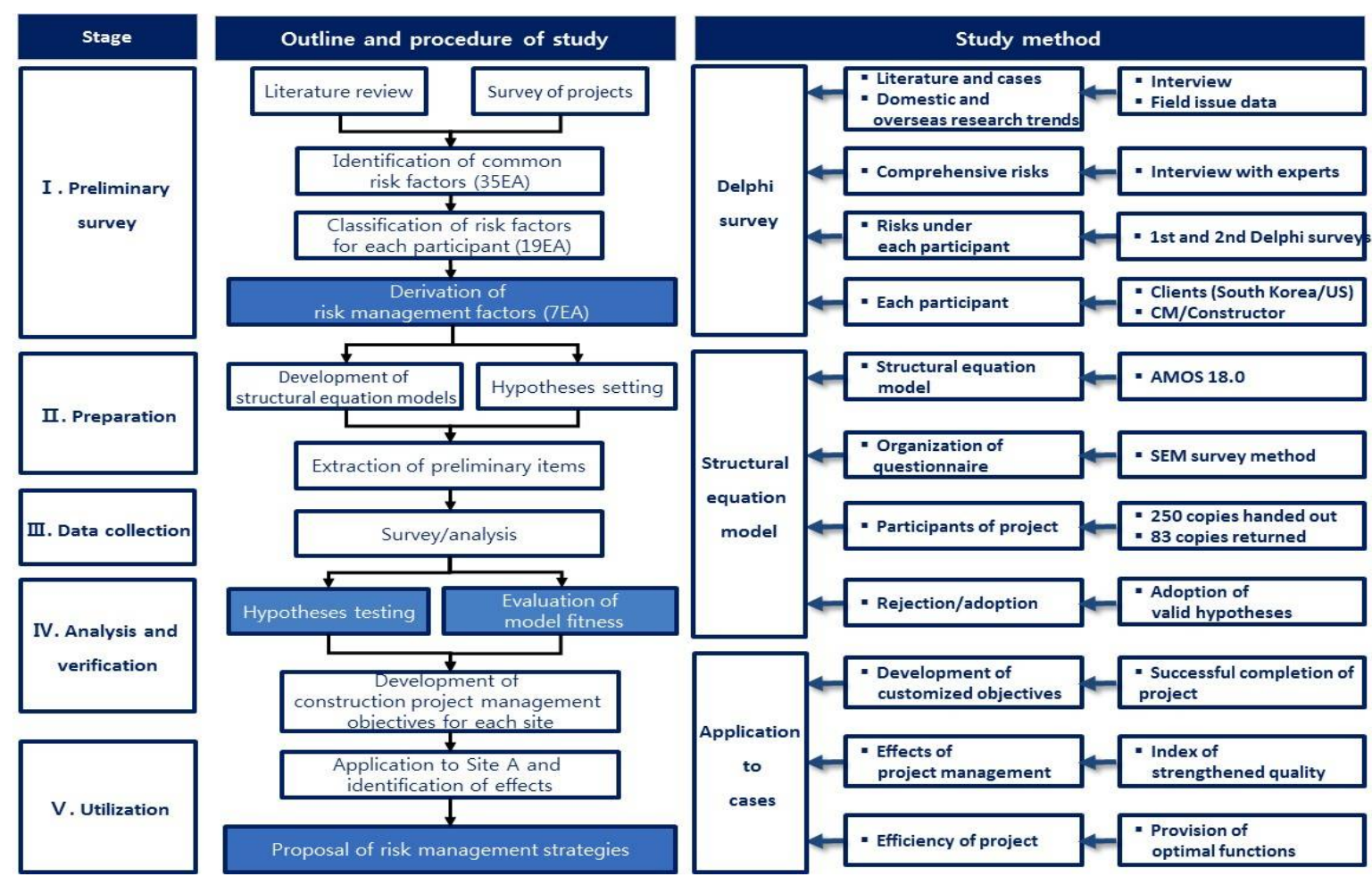

Figure 1. Research Framework

\section{Theoretical review}

\subsection{Research trend in risk factors}

There have been many studies on the risk management of construction projects, which can be summarized as in Table 1 below.

Table 1. Research trend in risk management

\begin{tabular}{|c|c|}
\hline Researchers & Summary \\
\hline Baloi et al. & $\begin{array}{l}\text {-Risk factors are derived from } 7 \text { categories including estimation, design, } \\
\text { competitiveness, building practice, construction, economy and politics [3]. }\end{array}$ \\
\hline Bing et al. & $\begin{array}{l}\cdot \mathrm{J} / \mathrm{V} \text { risk factors are presented based on project characteristics, internal and } \\
\text { external factors and Chinese cases [4]. }\end{array}$ \\
\hline Chan et al. & $\begin{array}{l}\text {-Risk factors are derived which are related to cultural difference and buildin } \\
\text { practice [5]. }\end{array}$ \\
\hline Han et al. & $\begin{array}{l}\text {-Risk factors are classified into politics, economy, culture, law, technology, } \\
\text { construction and other areas influencing projects [6]. }\end{array}$ \\
\hline Hastak et al. & $\begin{array}{l}\text { A risk assessment model (ICRAM-1) is proposed for the initial stage (plann } \\
\text { of an overseas construction project [7]. }\end{array}$ \\
\hline Mohamed & $\begin{array}{l}\text { instructability and risk factors is analyzed by us } \\
\text { ]. }\end{array}$ \\
\hline Pinto & $\begin{array}{l}\text { A regression analysis method is used to proposed a model, and } 10 \text { influenti } \\
\text { objectives including PJT range, management goal and communication with } \\
\text { clients are derived [9]. }\end{array}$ \\
\hline Wang et al. & $\begin{array}{l}\text {-Rick factors are identified from } 6 \text { areas including regulation, legal change, } \\
\text { corruption, delay in licensing and irresistible force [10]. }\end{array}$ \\
\hline Kim & $\begin{array}{l}\text { A case study for evaluating the financial capability of domestic companies } \\
\text { which want to advance into overseas construction markets [11]. }\end{array}$ \\
\hline
\end{tabular}


Lee et al.

- Potential risks of investment \& development projects are identified and analyzed by using the AHP technique and fuzzy theory [12].

Ahn et al.

-Key objectives are derived for each participant like constructor and design agency [13].

The previous studies provided lists of influential factors, which need to be considered for risk management of overseas construction projects, and proposed major management factors. However, the relationship between those influential factors and the performance of a project has not been concretely identified. In addition, many papers have analyzed the impact of each risk factor on the labour and material costs of an overseas construction project by focusing on financial, political and state-related risks. However, those analyses pay no attention to differential characteristics of each participant of a construction project. Risk factors of overseas construction projects have been continuously presented in many studies. Some studies identified risk factors related to constructability and causes of the failure of projects like influential objectives and cultural/political differences. The majority of studies have analyzed risks in the construction stage of an overseas construction project. However, only a few studies have focused on risks that could be occur due to various participants in a large construction site.

\subsection{Research trend in military installations project}

The following list concentrates in papers on construction project management for the construction of military installations.

Table 2. Research trend in military installations project

\begin{tabular}{|c|c|}
\hline Researchers & Summary \\
\hline Ko et al. & $\begin{array}{l}\text { Comprehensive project management (PM) and project management } \\
\text { organization (PMO) of USFK relocation plan are analyzed, and the current status } \\
\text { and problems of the project management of domestic parties are identified. } \\
\text { Strategies of development are proposed [14]. }\end{array}$ \\
\hline Kim et al. & $\begin{array}{l}\text { Cases of delay in the stage of signing MOU for the endowment \& concession } \\
\text { projects of the Ministry of National Defence, which are a part of the USFK } \\
\text { relocation plan, are analyzed [1]. }\end{array}$ \\
\hline Park et al. & $\begin{array}{l}\text { The new construction process is compared with the existing FFED project } \\
\text { process to identify problems and propose solutions [15]. }\end{array}$ \\
\hline Paik et al. & $\begin{array}{l}\text { A reference estimation model for USFK relocation plan is established and a } \\
\text { method of estimating concrete tasks and necessary manpower for each package } \\
\text { is proposed [16]. }\end{array}$ \\
\hline Seok et al. & $\begin{array}{l}\text {-Based on cases of each country, improvements of comprehensive management } \\
\text { of cost and schedule are derived, and an ordering model is proposed for the } \\
\text { integrated cost and schedule management, which is applicable to public agencies } \\
\text { [17]. }\end{array}$ \\
\hline Lee et al. & $\begin{array}{l}\text { Problems in the delay cases for each stage of the endowment \& concession } \\
\text { project are derived and improvements are presented [18]. }\end{array}$ \\
\hline Han et al. & $\begin{array}{l}\text { Cases of comprehensive project management for USFK relocation plan are } \\
\text { analyzed, and an EVMS-based reasonable method of estimating costs and } \\
\text { assessing performance is analyzed [2]. }\end{array}$ \\
\hline Hwang et al. & $\begin{array}{l}\text { System and constraints for information flow and implementation of tacks of } \\
\text { each stage of FED construction of soldiers' quarters are derived [19]. }\end{array}$ \\
\hline
\end{tabular}

Many studies analyzed cases of USFK relocation plan only to derive causes of delay and propose improvements of process. The institutional processes from the bidding stage to the early document submission stage were examined and the document processing during construction was clarified. Besides, the new land project in the US Army garrison was compared with the existing FED projects 
in order to identify problems and present management strategies. Nevertheless, those analyses of processes were based not on quantitative data but on experience.

In addition, the integrated management of schedule and cost, which is being applied to the USFK relocation plan, was analyzed and problems and improvements were identified. However, the proposed construction strategies focused only on cost and schedule. Accordingly, the quality requirement of FED was not considered by those studies. Moreover, although management cases of military installations projects, which were large-scale national projects, were analyzed, most of relevant data were confidential and not available to the public. For this reason, the analysis of such a case may be irrelevant to the present time.

As for methodology, AHP, the fuzzy theory and sensitivity analysis have been widely used. Some studies also used a structural equation model ([10], [20-21], [33]). However, the majority of the previous studies are theoretical and pay little attention on real cases for risk analysis.

There is no study that attempts to identify risk factors of a large-scale national relocation project of military installations, which attracts a lot of participants. Only a few case studies deal with such a project. Accordingly, in order to prevent and manage risks that could occur in any relocation plan of military installations, it is necessary to examine a structural relationship between risk factors by focusing on the case of YRP.

2.3 Research trend in structural equation models

A structural equation model is a technique of examining a structural relationship between potential factors and identifying a causal relationship. This method can reveal an influential relationship of variables between preceding and subsequent paths, and also enable a causal relationship between abstract variables or other variables, which can hardly be measured in a direct way, to be quantitatively analyzed.

The structural equation modeling is a statistical method of reflecting a measurement error and identifying a causal relationship through path coefficients. This method has been actively used in various areas like sociology, psychology and pedagogy. Recently, other areas of urban planning and structure, traffic and safety adopt a structural equation model to analyze the influential relations among multiple groups. This study used a structural equation model, since it can consider a measurement error for a variable and seems to be suitable for identifying a causal relationship by estimating direct or indirect effects of the mutual relation among participants and each risk factor on the construction management of the USFK relocation plan.

The main contents and limitations of the previous studies using a structural equation model can be summarized as follows. First, the necessity of risk management for overseas construction projects is dealt with. However, insufficient attention has been paid on such a complex interest of various participants in a large-scale project. Second, a structural equation model is used as an analysis method to identify causes and analyze factors. However, only policy suggestions have been provided by most studies. Third, the influential relation among variables of a structural equation model has been proved. However, only a few studies have been real cases.

Based on literature review, this study derives common risk factors by considering characteristics of each participant and quantitatively analyzes the influential relation among schedule, quality and cost. Such a quantitative analysis has been hardly attempted in the previous studies. Finally, in this study, hypotheses are tested and the results of the structural equation model are used to set up objectives of the risk management of a construction project on the basis of real field cases.

Table 3. Research trend in structural equation models 


\begin{tabular}{|c|c|}
\hline Researchers & Summary \\
\hline $\begin{array}{c}\text { Yang and } \\
\text { Ou, }\end{array}$ & $\begin{array}{l}\text { Causes of delay in the construction period of projects in Taiwan are derived, } \\
\text { and a structural equation model is used to quantitatively analyze a correlation } \\
\text { of each factor [20]. }\end{array}$ \\
\hline Kang et al, & $\begin{array}{l}\text { The impact of the maturity of integrated PM in overseas plant construction } \\
\text { sites on the performance of PJ is investigated. A structural equation model is } \\
\text { applied to propose strategies for effectively implementing the construction } \\
\text { projects of overseas plants [21]. }\end{array}$ \\
\hline Lee et al, & $\begin{array}{l}\text {-Latent variables and mediators, which affect constructability, are derived } \\
\text { through the interview with employees working on overseas construction } \\
\text { projects. A model for improving constructability is proposed based on a causal } \\
\text { relationship between influential factors [22]. }\end{array}$ \\
\hline Lee et al, & $\begin{array}{l}\text { Satisfaction of demanders of unsold houses was surveyed, and a structural } \\
\text { equation model was used to identify some policy-related suggestions and solve } \\
\text { the problem of unsold houses [23]. }\end{array}$ \\
\hline Yoon et al, & $\begin{array}{l}\text { The relationship between satisfaction of living in an apartment and U-City } \\
\text { service factors is analyzed, and some measures for improving U-City service } \\
\text { are proposed [24]. }\end{array}$ \\
\hline Yoon et al, & $\begin{array}{l}\text {-Users' satisfaction with the Construction Information Management System is } \\
\text { surveyed, and a structural equation model is implemented to analyze a causal } \\
\text { relationship affecting satisfaction with the system [25]. }\end{array}$ \\
\hline Kim et al, & $\begin{array}{l}\text {-Index concerning the mediation of conflicts, which occur during a } \\
\text { reconstruction project, is derived, and the impact of satisfaction with a project } \\
\text { on the decision to continue such a project is analyzed [26]. }\end{array}$ \\
\hline Hwang et al, & $\begin{array}{l}\text {-A structural equation model is used to analyze the relationship between eco- } \\
\text { friendly planning elements and high-rise residents' satisfaction with dwelling } \\
\text { (satisfaction, royalty and preference) [27]. }\end{array}$ \\
\hline Huh et al, & $\begin{array}{l}\text {-Influential factors on post evaluation of natural disaster prevention projects } \\
\text { are derived. A structural equation model is used to analyze the causal } \\
\text { relationship between the effects of such a project and items of post evaluation } \\
\text { and determine weights [28]. }\end{array}$ \\
\hline
\end{tabular}

\section{Derivation of risk factors and development of a structural equation model}

\subsection{Survey and interview}

Field data of YRP such as NCR and MaDTaG were surveyed. Based on those data, (weekly, monthly and biannual) regular reports about 7 projects for quarters and welfare facilities were comparatively analyzed in order to identify 35 common risk factors. To consider characteristics of such a large-scale national military installations project, an interview with 12 experts, who included military officials (MUROs, FED) having a 5-year or longer experience of YRP of USFK, construction professionals of 00 company and field staffs (K-C PMC), was conducted and the suitability of those risk factors was verified. In the open-ended interview, the conversation was both recorded and written down. Any excessive or abstract interpretation of terms used by the interviewees was excluded while analyzing the interview.

Among 35 risk factors, the one that was irrelevant to FED project was excluded. As regards sharing construction cost, another risk factor concerning the US special account project was also dismissed since it was beyond the study scope. Instead, risk factors of the endowment \& concession project, which was executed jointly by South Korea and the US, were selected. Redundant risk factors of each participants of the project were identified and only those which directly affected YRP were

${ }^{8}$ MND USFK Relocation Office 
selected. Risk factors of each unit project were deleted, and those which were commonly applied to the USFK relocation plan at the project level were selected. Among risk factors of the initial and design stages, those which did not currently occur due to the implementation of the project were excluded.

The interview results showed that domestic laws such as the Act on Contract with the State, the Construction Technology Promotion Act, and the Framework Act on the Construction Industry are not sufficiently compatible or consistent with the procedures of FED and FAR (Federal Acquisition Regulation). Accordingly, such a gap made it difficult to smoothly implement the construction projects. Based on the characteristics of the USFK relocation plan, 19 risk factors were selected for participants, as shown in Figure 2.

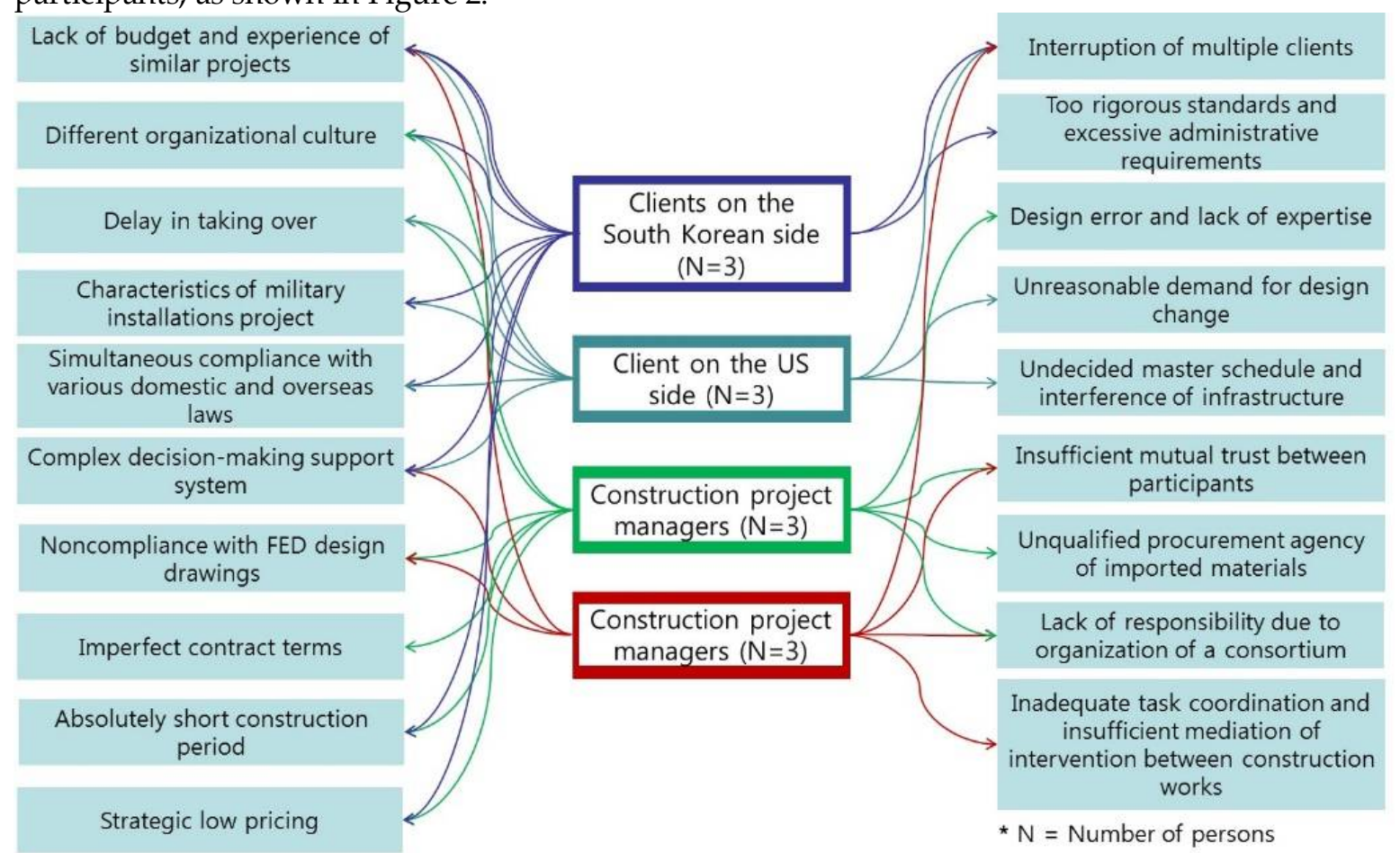

Figure 2. Correlation among Risk Factors by Stakeholders

\subsection{Determination of risk factors}

The adequacy of 19 risk factors, which were selected through the interview, was examined, and the Delphi technique was performed to identify the importance of each of those 19 factors and set up hypotheses of a structural equation model. Experts (participants and field managers) were selected by considering representativeness for the relocation project and sincerity of responses. The basic concept and goal of the study was explained to ask whether they would participate in the survey, which was conducted twice. Table 4 presents the survey result.

The survey consisted of interview and e-mail correspondence with 8 respondents including participants and field managers of YRP. In the first survey, an open-ended questionnaire was handed out. The respondents were asked to choose which one among those 19 risk factors was considered to be important factors for efficient project management in the field. In case any items have redundant meanings or were to be revised, addition opinions were received and those risk factors were reorganized.

The second survey was conducted by using closed-ended questions based on the result of the first survey. The Likert 5-point scale was used as the response scale [29]. The names of risk factors thus selected were modified to clarify meanings by receiving participants' opinions.

Table 4 presents participants' awareness of risk factors. Risk factors with response rate of $50 \%$ or below were excluded since they seemed to be less important and caused serious disagreement 
among respondents. 7 risk factors with response rate of $75 \%$ or above were selected and used to set up hypotheses and identify a quantitative correlation through a structural equation model.

Table. 4. Result of Delphi survey (Unit: Person)

\begin{tabular}{|c|c|c|c|c|c|}
\hline \multirow[b]{2}{*}{ Stakeholder Risk Factors } & \multicolumn{4}{|c|}{ Number of respondents } & \multirow[b]{2}{*}{$\begin{array}{l}\text { Respon } \\
\text { se rate } \\
(\%)\end{array}$} \\
\hline & $\begin{array}{c}\text { LH, } \\
\text { MURO }\end{array}$ & FED & $\begin{array}{c}\text { Construct } \\
\text { or \& } \\
\text { Designer }\end{array}$ & $\mathrm{CMr}$ & \\
\hline Interruption of multiple clients & 2 & 2 & 2 & 1 & $7(88 \%)$ \\
\hline Delay in taking over & 2 & & 2 & & $4(50 \%)$ \\
\hline Characteristics of military installations project & 1 & 1 & 2 & 2 & $6(75 \%)$ \\
\hline $\begin{array}{l}\text { Inadequate task coordination and insufficient } \\
\text { mediation of intervention between } \\
\text { construction works }\end{array}$ & 2 & & 2 & & $4(50 \%)$ \\
\hline Insufficient mutual trust between participants & & 1 & & 2 & $3(38 \%)$ \\
\hline $\begin{array}{l}\text { Lack of budget and experience of similar } \\
\text { projects }\end{array}$ & 2 & & & 2 & $4(50 \%)$ \\
\hline Different organizational culture & 1 & 1 & 2 & & $4(50 \%)$ \\
\hline Unreasonable demand for design change & 2 & 1 & 2 & 2 & $7(88 \%)$ \\
\hline $\begin{array}{l}\text { Unqualified procurement agency of imported } \\
\text { materials }\end{array}$ & 2 & 1 & 2 & 1 & $6(75 \%)$ \\
\hline $\begin{array}{l}\text { Lack of responsibility due to organization of a } \\
\text { consortium }\end{array}$ & 2 & & 2 & & $4(50 \%)$ \\
\hline Complex decision-making support system & & & 2 & 2 & $4(50 \%)$ \\
\hline Design error and lack of expertise & 2 & 1 & 1 & & $4(50 \%)$ \\
\hline $\begin{array}{l}\text { Too rigorous standards and excessive } \\
\text { administrative requirements }\end{array}$ & & & 2 & 2 & $4(50 \%)$ \\
\hline Absolutely short construction period & 2 & 1 & 2 & 2 & $7(88 \%)$ \\
\hline $\begin{array}{l}\text { Simultaneous compliance with various } \\
\text { domestic and overseas laws }\end{array}$ & 1 & & 2 & 1 & $4(50 \%)$ \\
\hline Noncompliance with FED design drawings & 2 & 2 & 1 & 2 & $7(88 \%)$ \\
\hline $\begin{array}{l}\text { Undecided master schedule and interference of } \\
\text { infrastructure }\end{array}$ & 2 & 1 & 2 & 2 & $7(88 \%)$ \\
\hline Strategic low pricing & 2 & & & 2 & $4(50 \%)$ \\
\hline Imperfect contract terms & 2 & & 2 & & $4(50 \%)$ \\
\hline
\end{tabular}

\subsection{Development of a structural equation model}

Multiple correlation of risk factors, which were derived by using the Delphi technique, was identified, and a schematic structural equation model of Figure 3 was set up in order to manage risk factors damaging the efficiency of construction project management. 


\section{(A) Risk management factors}

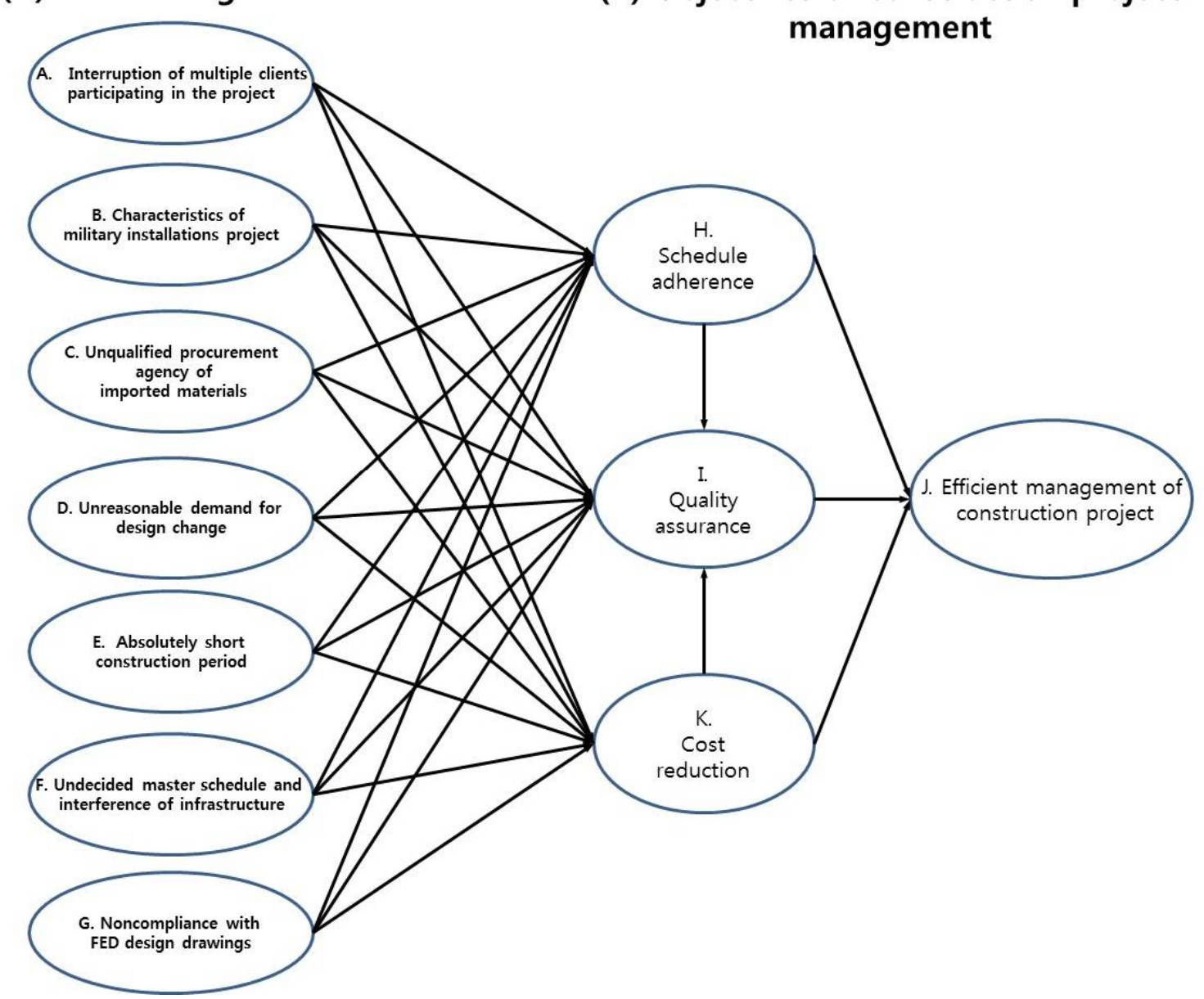

\section{(B) Objectives of construction project} management

Figure 3. Structural equation modeling

The above paths express the relation between risk factors (A), which were obtained from literature review, interview and the Delphi method, and objectives (B). The paths indicate predictive relationship and correlations between risk factors. Risk factors are marked in oval shapes and their relationship is expressed by arrows. Many studies including Baccarini and Pinto and Slevin et al, set schedule, quality and cost as risk objectives (B), which are used as the performance components of a project. [30-31]

The safety and environment area of FED project is rigorously managed by each participant in accordance with relevant laws and regulations of South Korea (Ministry of Labor/ Korea Occupational Safety \& Health Agency), US DoD standards (EM 385-1-1/USFK Pamphlet \& USACE Manual) and FED specifications. In case there is disagreement of regulation, rule and requirement between South Korea and the US, the strictest requirement is to be applied to site so that the construction can be prevented from being suspended due to safety and environmental issues. Accordingly, since the survey and interview showed that the safety \& environment area was a risk factor, which could be proactively solved, this area was excluded while deriving the objectives of risk management (B). As shown in Figure 3, the objectives (B) are connected to risk factors (A) in a complex way.

After the multiple correlations among risk factors were identified, the following hypotheses were set in order to identify and manage risk factors that could decrease the efficiency of construction project management.

1) Hypothesis concerning risk of each participant

- Risk of each participant in a relocation project of military installations has a positive (+) im pact on quality, cost and schedule.

2) Hypothesis concerning risk of technology management 
- Risk of technology management in a relocation project of military installations has a positive (+) impact on quality, cost and schedule.

3) Hypothesis concerning risk of law and contract

- Risk of law and contract in a relocation project of military installations has a positive (+) i mpact on quality, cost and schedule.

4) Hypothesis concerning the relationship among quality, cost, schedule and construction proje ct management

- Schedule and cost of a relocation project of military installations have a positive (+) impact on quality.

- Quality, schedule and cost of a relocation project of military installations have a positive (

+) impact on construction project management.

\section{Analysis of the structural equation modeling result}

\subsection{Data collection and selection of evaluation group}

Interview with experts was conducted to examine the adequacy of YRP risk factors and test the research hypotheses.

The population for this study consisted of participants of the field works of YRP, which included designer, constructor, construction project manager, US clients (FED, DPW) and South Korean clients (LH, MURO) of YRP, located around Dodoo-ri, Pyeongtaek-si, Gyeonggi-do.

The questionnaire was handed out to 250 experts five times from June 1, 2015 to February 1, 2016. 83 experts responded to the survey, which corresponded to the response rate of $33.2 \%$. As 5 questionnaires, which were returned but showed inconsistency, were excluded, the remaining 78 questionnaires were finally analyzed.

4.2 Analysis for testing hypotheses

The research hypotheses were tested by using a path analysis and a structural equation model. Before testing the hypotheses, reliability, validity and correlation of measurement items, which were utilized for testing hypotheses, were analyzed. The SPSS WIN 12.0K program was implemented to statistically process valid samples of responses [32]. A frequency analysis was conducted for the first time to identify characteristics of samples and variables. The reliability and validity of samples collected were analyzed. To test the study hypotheses, a confirmatory factor analysis was performed by using a structural equation model. The paths were analyzed based on the result of the factor analysis.

4.2.1 Measurement of reliability of risk

Before verifying the structural equation model and testing the study hypotheses, the reliability of measurement items were examined in order to see how consistent the measurement was. The reliability was checked by using the variance of measured values, which was obtained by repeating the measurement. The degree of reliability was measured by using the Cronbach's alpha $(\alpha)$ for a set of two or more latent variables. Confidence coefficients between 0 and 1 were checked.

In this study, Cronbach's $\alpha$ coefficients were derived for measurement items of each variable, which were presented in Table 5. If a Cronbach's $\alpha$ coefficient is 0.6 or above, reliability turns out to be ensured. The number of measurement items and the value of Cronbach's $\alpha$ for each variable were between 0.705 and 0.916 , as shown below, and thus satisfied the criterion. It turned out that every factor had high internal consistency.

As the values of Cronbach's $\alpha$ for the variables from A to J of Table 5 were 0.7 or above, those variables ensured good reliability. 
Table 5. Reliability of measurement items

\begin{tabular}{|c|c|c|c|}
\hline Variables & $\begin{array}{c}\text { Initial } \\
\text { number of } \\
\text { items }\end{array}$ & $\begin{array}{c}\text { Ultimate } \\
\text { number of } \\
\text { items* }\end{array}$ & $\begin{array}{c}\text { Cronbach's } \\
\alpha\end{array}$ \\
\hline A. Interruption of multiple clients & 3 & 3 & 0.847 \\
\hline B. Characteristics of military installations project & 3 & 3 & 0.833 \\
\hline $\begin{array}{l}\text { C. Unqualified procurement agency of imported } \\
\text { materials }\end{array}$ & 3 & 3 & 0.853 \\
\hline D. Unreasonable demand for design change & 3 & 3 & 0.736 \\
\hline E. Absolutely short construction period & 3 & 3 & 0.701 \\
\hline $\begin{array}{l}\text { F. Undecided master schedule and interference of } \\
\text { infrastructure }\end{array}$ & 3 & 3 & 0.763 \\
\hline G. Noncompliance with FED design drawings & 3 & 3 & 0.841 \\
\hline K. Cost reduction & 3 & 3 & 0.888 \\
\hline I. Quality assurance & 3 & 3 & 0.906 \\
\hline H. Schedule adherence & 3 & 2 & 0.928 \\
\hline J. Efficient management of construction project & 3 & 2 & 0.759 \\
\hline
\end{tabular}

* Some items (J-3 and K-3) are excluded based on the reliability analysis and the exploratory factor analysis using SPSS.

\subsubsection{Analysis of validity of risk}

Both exploratory and confirmatory factor analyses were conducted in order to see whether the characteristics and properties of risk factors to be measured were accurate.

Since hypotheses concerning factors were set based on literature review, the validity of each latent variable could be verified by conducting a confirmatory factor analysis. However, as the measurement of influential factors was hardly dealt with in the existing studies, the exploratory factor analysis was performed before the confirmatory factor analysis. The validity of the hypotheses set for the factors in this study was confirmed by exploring the basic structure of variable.

1) Exploratory factor analysis

A principal component analysis was conducted to see the validity of each variable presented by the structural equation model. Among latent variables of three components of risk objectives (B), the factor loading of the schedule ' $\mathrm{K}-3^{\prime}$ ' was 0.438 and that of the efficient construction project management ' J-3' was 0.409. In other words, both items (K-3 and J-3) had the explanation powers of less than $50 \%$. Accordingly, they were excluded from the analysis.

Table 6. Results of exploratory factor analysis

\begin{tabular}{cccccccccccc}
\hline \multirow{2}{*}{ Variable } & \multicolumn{10}{c}{ Factor loading } \\
\cline { 2 - 11 } & A & B & C & D & E & F & G & H & I & J & K \\
\hline A-1 & 0.769 & - & - & - & - & - & - & - & - & - & - \\
A-2 & 0.758 & - & - & - & - & - & - & - & - & - & - \\
A-3 & 0.581 & - & - & - & - & - & - & - & - & - & - \\
B-1 & - & 0.905 & - & - & - & - & - & - & - & - & - \\
B-2 & - & 0.868 & - & - & - & - & - & - & - & - & - \\
B-3 & - & 0.82 & - & - & - & - & - & - & - & - & - \\
C-1 & - & - & 0.826 & - & - & - & - & - & - & - & - \\
C-2 & - & - & 0.757 & - & - & - & - & - & - & - & - \\
C-3 & - & - & 0.594 & - & - & - & - & - & - & - & - \\
D-1 & - & - & - & 0.81 & - & - & - & - & - & - & -
\end{tabular}




\begin{tabular}{llllllllllll} 
D-2 & - & - & - & 0.709 & - & - & - & - & - & - & - \\
D-3 & - & - & - & 0.657 & - & - & - & - & - & - & - \\
E-1 & - & - & - & - & 0.823 & - & - & - & - & - & - \\
E-2 & - & - & - & - & 0.809 & - & - & - & - & - & - \\
E-3 & - & - & - & - & 0.667 & - & - & - & - & - & - \\
F-1 & - & - & - & - & - & 0.794 & - & - & - & - & - \\
F-2 & - & - & - & - & - & 0.724 & - & - & - & - & - \\
F-3 & - & - & - & - & - & 0.716 & - & - & - & - & - \\
G-1 & - & - & - & - & - & - & 0.879 & - & - & - & - \\
G-2 & - & - & - & - & - & - & 0.872 & - & - & - & - \\
G-3 & - & - & - & - & - & - & 0.487 & - & - & - & - \\
H-1 & - & - & - & - & - & - & - & 0.785 & - & - & - \\
H-2 & - & - & - & - & - & - & - & 0.782 & - & - & - \\
H-3 & - & - & - & - & - & - & - & 0.653 & - & - & - \\
I-1 & - & - & - & - & - & - & - & - & 0.778 & - & - \\
I-2 & - & - & - & - & - & - & - & - & 0.741 & - & - \\
I-3 & - & - & - & - & - & - & - & - & 0.609 & - & - \\
K-1 & - & - & - & - & - & - & - & - & - & 0.864 & - \\
K-2 & - & - & - & - & - & - & - & - & - & 0.839 & - \\
K-3 & - & - & - & - & - & - & - & - & - & 0.438 & - \\
J-1 & - & - & - & - & - & - & - & - & - & - & 0.786 \\
J-2 & - & - & - & - & - & - & - & - & - & - & 0.687 \\
J-3 & - & - & - & - & - & - & - & - & - & - & 0.409 \\
\hline
\end{tabular}

The exploratory factor analysis showed that 7 factors including the interruption of multiple clients and the characteristics of military installations project were latent variables. 3 factors of cost, quality and schedule turned out to be mediators, and the efficient construction project management was a dependent variable. Except K-3 and J-3, the remaining factors had the explanation power of $50 \%$ or above, indicating validity. Table 6 presents results.

2) Confirmatory factor analysis

The hypotheses of the structural equation model were tested by using AMOS 18.0. Factor loading $(\lambda)$ between a mediator and a latent variable was examined through the confirmatory factor analysis based on the method of the maximum likelihood estimation.

11 variables were applied to each model. The overall results of the confirmative factor an alysis showed that every mediator had a good factor loading $(\lambda>0.60)$ for a latent variable. The measurements of factor loading seemed to reflect mediators (observed variables) explainin $\mathrm{g}$ latent variables in this study. In addition, every mediator not only showed a good factor lo ading for a latent variable but also had a significant $\mathrm{t}$-value (= unstandardized coefficient/stan dard error) of at least 1.965. As shown in Table 7, the model of the confirmatory factor analy sis showed good fitness 9 with $\chi 2=600.47,(\mathrm{df}=379) \mathrm{p}=.000$, GFI $=0.851$, AGFI $=0.805, \mathrm{CFI}=$ $0.915, \mathrm{RMR}=0.029$ and RMSEA $=0.054$.

A correlation analysis was performed to see the relationship between factors that were in vestigated. Every factor was a continuous variable satisfying normality. As for the influence $b$ etween factors, the majority of correlations showed a positive (+) direction, which was consist ent with the hypotheses.

${ }^{9} \mathrm{X} 2 / \mathrm{df} \leq 3.0$ is adopted and $\mathrm{X} 2 / \mathrm{df} \leq 2.0$ is (conservatively) adopted. $\mathrm{P}$ value $\leq 0.05$ is adopted. GFI $\geq 0.9$ and AGFI $\geq 0.9$ can be adopted. In case GFI and AGFI are not adopted, CFI $\geq 0.9$ can be adopted. R MSEA $\leq 0.08$ is adopted. RMR $\leq 0.1$ is adopted and $R M R \leq 0.05$ is desirable. 
Table 7. Results of confirmatory factor analysis

\begin{tabular}{cccccccc}
\hline & $\begin{array}{c}\text { Path } \\
\text { (Factor }\end{array}$ Variable) & $\begin{array}{c}\text { Unstandardized } \\
\text { coefficient }\end{array}$ & $\begin{array}{c}\text { Standard } \\
\text { error }\end{array}$ & t-value & P & $\begin{array}{c}\text { Factor } \\
\text { loading }\end{array}$ \\
\hline A & $\rightarrow$ & A-1 & 1.000 & Fix & - & - & 0.647 \\
A & $\rightarrow$ & A-2 & 1.228 & 0.146 & 8.441 & 0.000 & 0.773 \\
A & $\rightarrow$ & A-3 & 1.266 & 0.150 & 8.432 & 0.000 & 0.772 \\
B & $\rightarrow$ & B-1 & 1.000 & Fix & - & - & 0.956 \\
B & $\rightarrow$ & B-2 & 0.906 & 0.055 & 16.627 & 0.000 & 0.852 \\
B & $\rightarrow$ & B-3 & 0.861 & 0.060 & 14.344 & 0.000 & 0.781 \\
C & $\rightarrow$ & C-1 & 1.000 & Fix & - & - & 0.753 \\
C & $\rightarrow$ & C-2 & 1.667 & 0.153 & 10.879 & 0.000 & 1.020 \\
C & $\rightarrow$ & C-3 & 0.547 & 0.093 & 5.881 & 0.000 & 0.401 \\
D & $\rightarrow$ & D-1 & 1.000 & Fix & - & - & 0.696 \\
D & $\rightarrow$ & D-2 & 1.031 & 0.118 & 8.735 & 0.000 & 0.756 \\
D & $\rightarrow$ & D-3 & 1.025 & 0.123 & 8.316 & 0.000 & 0.704 \\
E & $\rightarrow$ & E-1 & 1.000 & Fix & - & - & 0.794 \\
E & $\rightarrow$ & E-2 & 1.093 & 0.104 & 10.515 & 0.000 & 0.855 \\
E & $\rightarrow$ & E-3 & 0.826 & 0.099 & 8.370 & 0.000 & 0.619 \\
F & $\rightarrow$ & F-1 & 1.000 & Fix & - & - & 0.817 \\
F & $\rightarrow$ & F-2 & 0.774 & 0.095 & 8.180 & 0.000 & 0.634 \\
F & $\rightarrow$ & F-3 & 0.911 & 0.098 & 9.277 & 0.000 & 0.743 \\
G & $\rightarrow$ & G-1 & 1.000 & Fix & - & - & 0.904 \\
G & $\rightarrow$ & G-2 & 1.021 & 0.100 & 10.201 & 0.000 & 0.884 \\
G & $\rightarrow$ & G-3 & 0.467 & 0.080 & 5.876 & 0.000 & 0.426 \\
H & $\rightarrow$ & H-1 & 1.000 & Fix & - & - & 0.767 \\
H & $\rightarrow$ & H-2 & 0.887 & 0.107 & 8.293 & 0.000 & 0.690 \\
H & $\rightarrow$ & H-3 & 0.929 & 0.113 & 8.260 & 0.000 & 0.686 \\
I & $\rightarrow$ & I-1 & 1.000 & Fix & - & - & 0.698 \\
I & $\rightarrow$ & I-2 & 0.995 & 0.121 & 8.201 & 0.000 & 0.706 \\
I & $\rightarrow$ & I-3 & 1.059 & 0.126 & 8.376 & 0.000 & 0.728 \\
K & $\rightarrow$ & K-1 & 1.000 & Fix & - & - & 0.632 \\
K & $\rightarrow$ & K-2 & 1.395 & 0.228 & 6.130 & 0.000 & 0.775 \\
J & $\rightarrow$ & J-1 & 1.000 & Fix & - & - & 0.776 \\
J & $\rightarrow$ & J-2 & 1.172 & 0.179 & 6.541 & 0.000 & 0.907 \\
\hline & $*$ & Significance probability (P) $<0.05($ Adopted) & Significance & probability & $(\mathrm{P})>0.05($ Rejected) \\
& & & & & &
\end{tabular}

4.3 Testing hypotheses of a structural equation model

A structural equation model was set up for the study hypotheses formulated above. The hypotheses were tested to evaluate the efficiency of construction project management for YRP and establish a strategy for risk management.

The fitness of the structural equation model was indicated by $\chi 2=632.012(\mathrm{df}=389) \mathrm{p}=.000$, GFI $=0.848, \mathrm{AGFI}=0.807, \mathrm{CFI}=0.907, \mathrm{RMR}=0.035$ and RMSEA $=0.056$. The assumption "the risk factors (A: 7EA) of the military installations relocation project affect schedule, quality and cost, which has a significant effect on the efficiency of construction project management." was significant with the confidence interval of $95 \%$.

For the above 14 hypotheses concerning risk of each participant, risk of technology management, risk of law and contract and the relationship among schedule $(\mathrm{H})$, quality $(\mathrm{I})$, cost $(\mathrm{K})$ and efficiency of construction project management $(\mathrm{J})$, if the fitness point $(\mathrm{P})$ of the measurement model is 0.05 or below, a hypothesis is adopted, and if the fitness point $(\mathrm{P})$ is over 0.05 , a hypothesis is rejected. Table 8 presents the results of adoption and rejection. 
Table 8. Path coefficients of study hypotheses

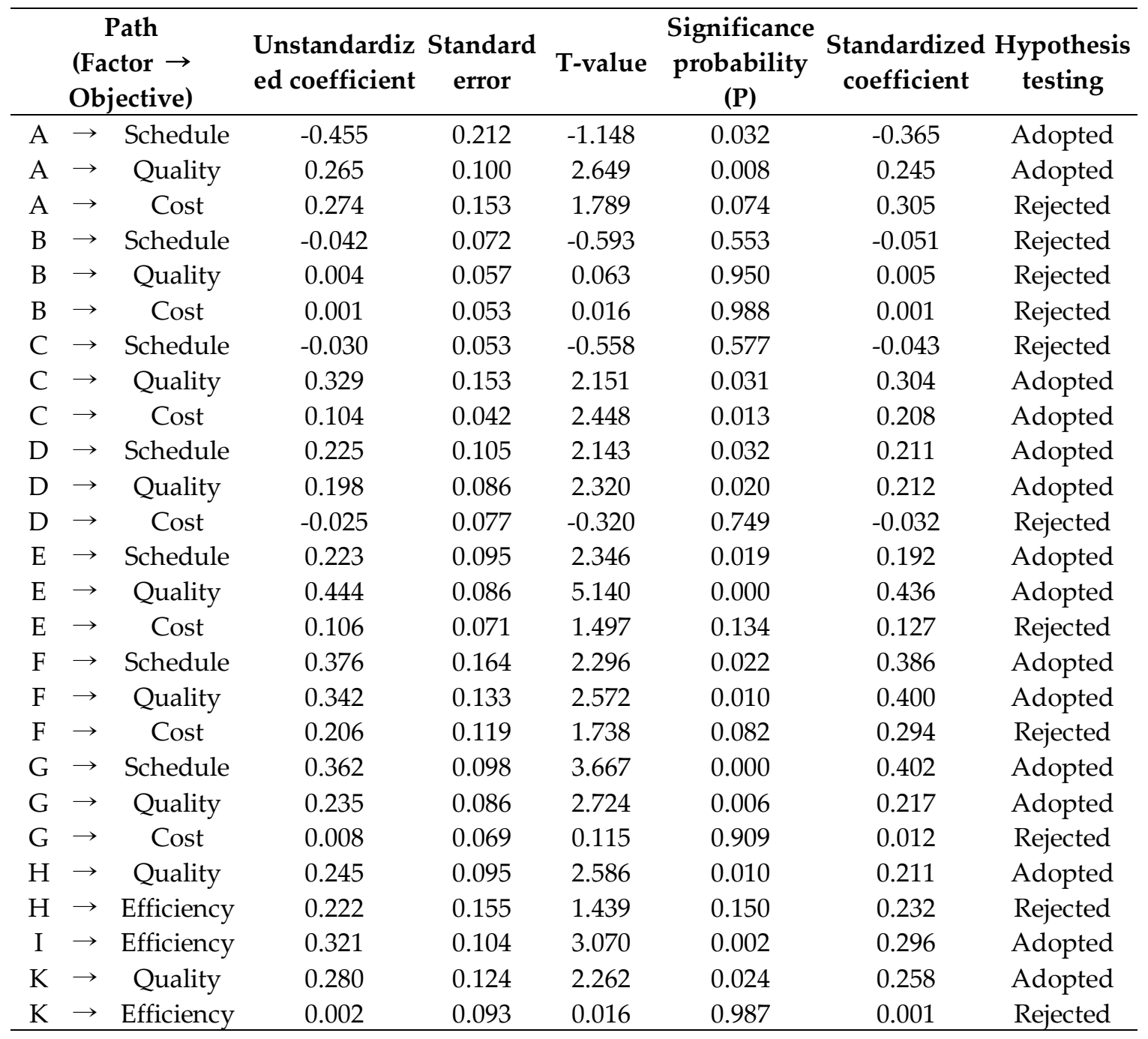

* Significance probability $(\mathrm{P})<0.05$ (Adopted), Significance probability $(\mathrm{P})>0.05$ (Rejected)

Figure 4 illustrates the analysis result of the structural equation model. A solid line indic ates the adoption of a hypothesis, while a dotted line means the rejection of a hypothesis. As for the analysis results for each factor, quality and schedule were significantly affected by suc $\mathrm{h}$ factors as the interruption of multiple clients participating in the project, the Absolutely sho rt construction period, the unqualified procurement agency of imported materials, and the un decided master schedule and interference of infrastructure. Most of risk factors, of which hyp otheses were adopted, tended to more positively $(+)$ related to quality than schedule and cost.

Quality and cost were significantly affected by such factors as the unreasonable demand for design change and the noncompliance with FED design drawings. There was no hypothesi $\mathrm{s}$ that was adopted by covering schedule, quality and cost. 


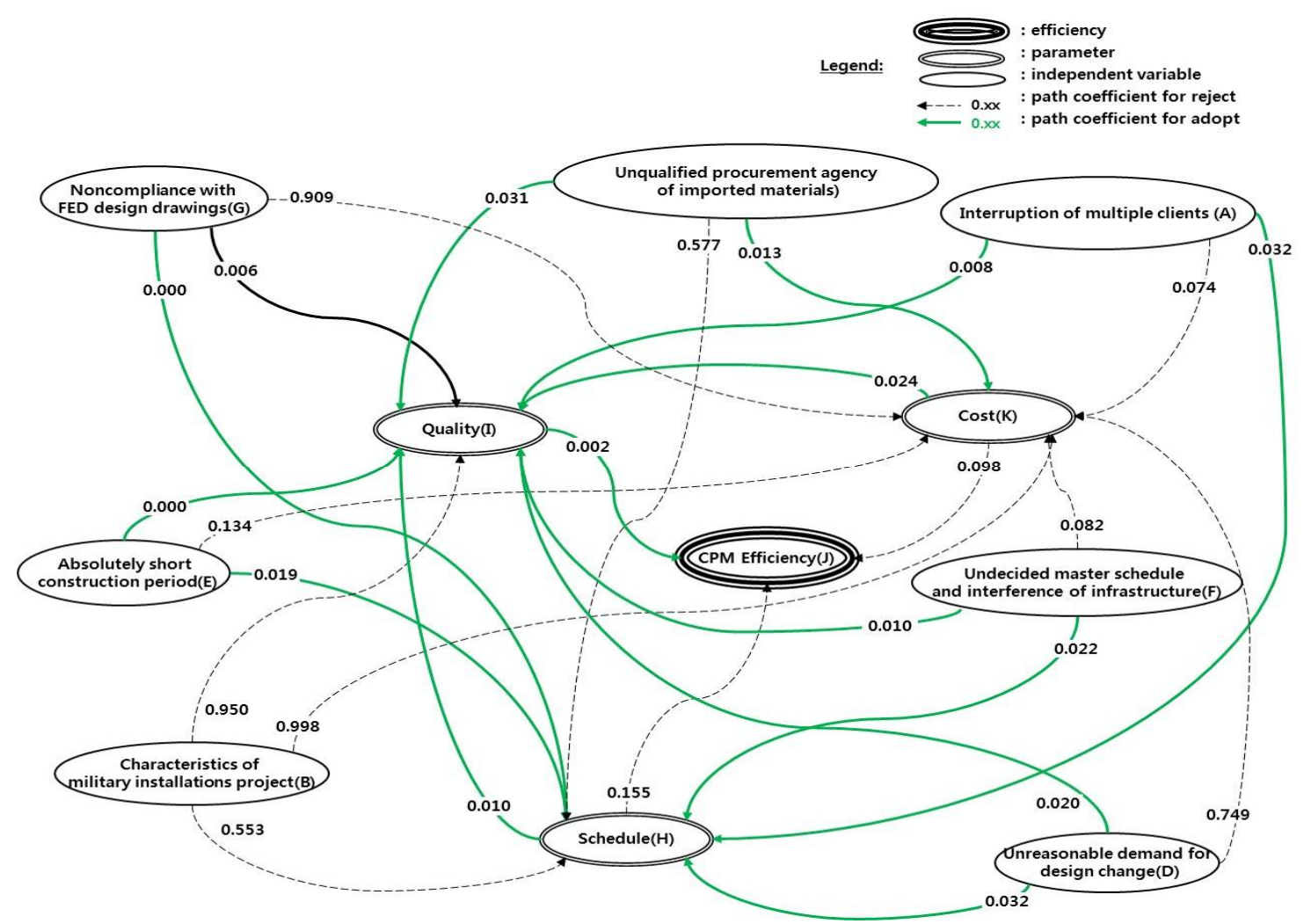

Figure 4. Analysis results of the structural equation model

Based on the results of the structural equation model, objectives of construction project $\mathrm{m}$ anagement, which were applicable to YRP site, were set as presented in Table 9. The objectiv es were applied to the major risk factors of Site A, thereby verifying their effects.

Table 9. Objectives of construction project management for each site

\begin{tabular}{|c|c|c|c|c|}
\hline Classification & $\begin{array}{l}\text { Management of } \\
\text { construction } \\
\text { commencement }\end{array}$ & $\begin{array}{l}\text { Submission } \\
\text { management }\end{array}$ & $\begin{array}{c}\text { Field } \\
\text { support } \\
\text { /inspection }\end{array}$ & $\begin{array}{l}\text { Education } \\
\text { /evaluation } \\
\text { management }\end{array}$ \\
\hline $\begin{array}{l}\text { A. Interruption of multiple } \\
\text { clients }\end{array}$ & $\bullet$ & ○ & $\Delta$ & $\bullet$ \\
\hline $\begin{array}{l}\text { B. Characteristics of military } \\
\text { installations project }\end{array}$ & $\Delta$ & $\Delta$ & $\circ$ & \\
\hline $\begin{array}{l}\text { C. Unqualified procurement } \\
\text { agency of imported materials }\end{array}$ & ○ & $\bullet$ & ○ & ○ \\
\hline $\begin{array}{l}\text { D. Unreasonable demand for } \\
\text { design change }\end{array}$ & & $\Delta$ & $\bullet$ & $\bullet$ \\
\hline $\begin{array}{l}\text { E. Absolutely short construction } \\
\text { period }\end{array}$ & $\bullet$ & $\bullet$ & $\circ$ & ० \\
\hline $\begin{array}{l}\text { F. Undecided master schedule } \\
\text { and interference of } \\
\text { infrastructure }\end{array}$ & ○ & & $\Delta$ & $\Delta$ \\
\hline $\begin{array}{c}\text { G. Noncompliance with FED } \\
\text { design drawings }\end{array}$ & ○ & ० & ○ & $\bullet$ \\
\hline
\end{tabular}

As shown in Table 9, objectives of construction project management, which were applicab le to the sites of YRP, were established. However, there were risk factors that needed to be $\mathrm{s}$ eparately solved.

Among risk factors, the 'determination of FED master schedule' should be proactively sol ved. Since MP (Master Plan) affects the commissioning schedule of each site, it needs to be so 
lved separately from the management objectives in YRP.

\subsection{Field application of construction project management objectives}

Construction project management objectives, which were applicable to real YRP sites, wer e proposed based on risk factors selected from hypothesis testing. The effects of those objectiv es were identified by field application.

This study applied the construction project management objectives to Site A, which corre sponded to the early stage of YRP with respect of data collection and military security. Table 10 presents the results.

Table 10. Application of the construction project management objectives and cost reduction effects

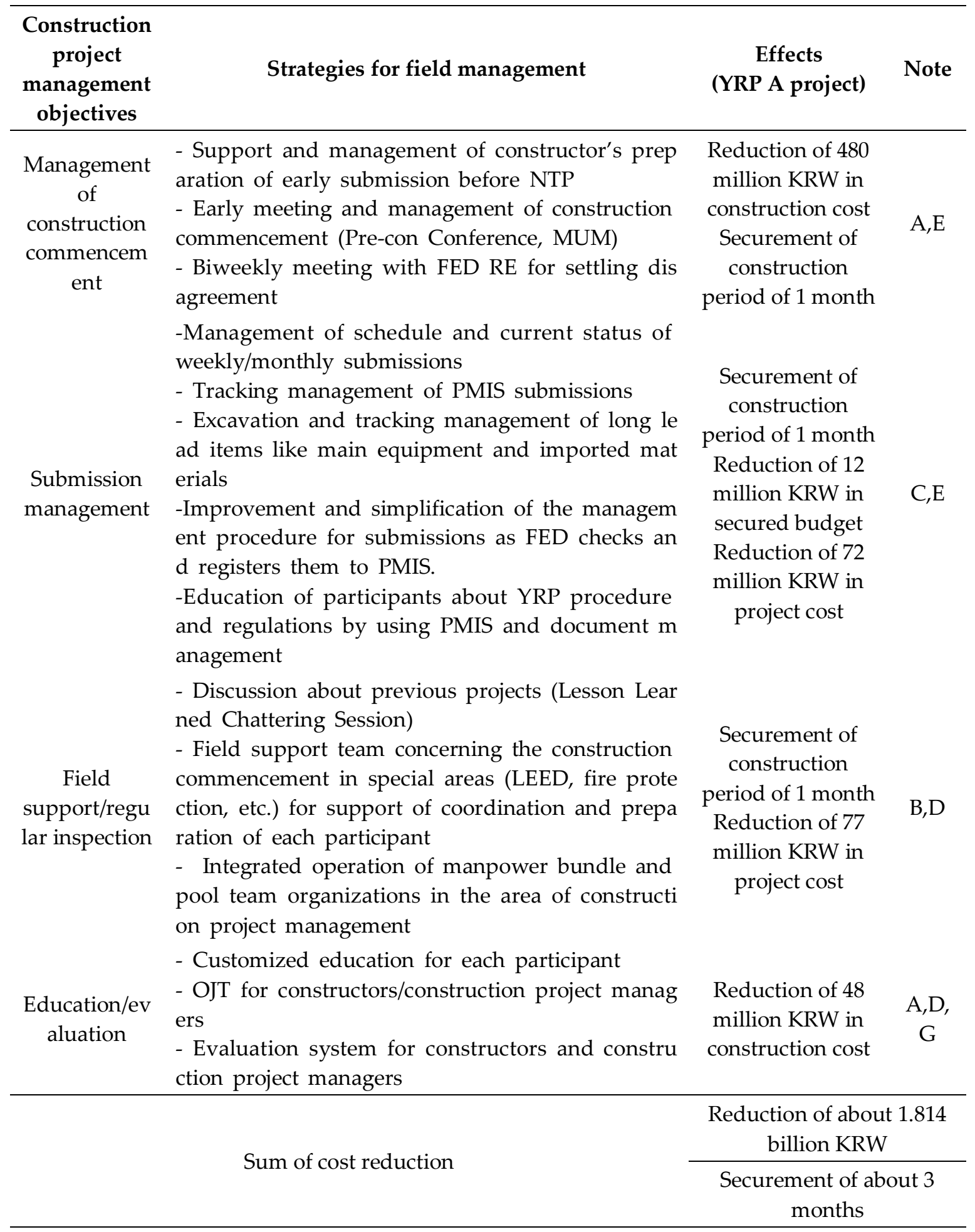


As for construction project management objectives in Site A, for construction commencem ent, constructors prepared the construction review specified by a domestic law and FED early submissions according to DOD standard like Eng. Form 4288, Joint Site Inventory, and Diggin g Permit, Site/Building Release Request. While the early submissions were prepared, various a pproval processes, which had to be completed within 90 days after NTP (Notice to Proceed) was issued, were implemented immediately after the commencement of construction. Those pr ocesses include Pre-construction Conference (NTP+10Day), Contractor's Quality Control Plan ( NTP+30Day) and Lab Certification (NTP+30Day). In this way, the risk factor of intervention of multiple clients was controlled so that relevant delays could be prevented in advance.

At the same time, for the management of submissions, construction project managers imp roved the procedure of submission management so that each organization could complete the preparation of piling work within 60 days after issuing NTP by preliminary review and discu ssion. Accordingly, any delays in decision-making due to responsibility issue during the appr oval process could be prevented and additional 30 days of construction period could be secur ed.

For field support during the construction work, clients on the South Korean side held a biweekly meeting with construction project managers and FED RE to settle current issues. Var ious procedures of YRP were reviewed and program-level discussion was made to reduce Pen ding items. Accordingly, various different laws and regulations could be simultaneously satisfi ed and the communication efficiency could be improved.

For field evaluation, construction project managers held a meeting on previous projects ( Lesson Learned Chattering Session) to propagate success and failure cases of similar PJT and secure an early period of commencement. Quarterly QC and QA evaluation system was imple mented in order to prevent any delay of submissions in each site. Besides, an incentive syste $\mathrm{m}$ could improve the quality of project.

For management of equipment and materials among submissions, constructors and design ers tracked and managed the status (4025 unapproved items, reason for delay and measure) o $\mathrm{f}$ submissions on PMIS in accordance with Eng. Form 4025 and weekly/monthly submission sc hedule. Important equipment and imported materials were classified as long lead items for se parate tracking management. In this way, delivery delays of subcontractors could be prevente d.

In field education, construction project managers checked the unified facility code (UFC) and specifications of similar PJT in advance. Accordingly, unreasonable design change could $\mathrm{b}$ e minimized to prevent the problem of design change when the construction was completed ( during the inspection of completion).

For field support, a design change TF was organized, and end-user's requirements at the level of Charette report and early CP (Criteria Package) were reaffirmed. Thus, the omission o $\mathrm{f}$ initial design review like RFI (Request for Information), noncompliance with FED design dra wings and other problems could be prevented. In addition, as any design changes due to DP $\mathrm{W}$ at the completion stage and the participation of end-users was responded in advance, the $\mathrm{f}$ actors of design change were excluded.

During the field education, various RFI/design change data of previous projects were sha red. As for the on-site RFI, the field QAR examined the submissions of constructors beforehan $\mathrm{d}$ so that issues, which could be dealt with on site, were settled and the remaining issues we re transmitted to the DM team. Thus, the period of design review could be shortened.

If the results of this study are used to derive variables, which need to be preferentially c ontrolled for management of similar projects in the future, and to establish strategies, costs wi 11 be reduced, any unnecessary delay of construction period will be prevented and structures with satisfactory quality will be taken over to end-users.

\section{Conclusion}


Although many domestic and overseas leading construction companies participate in YR $\mathrm{P}$, the failure of risk management has resulted in the schedule delay in construction. This stu dy has derived risk factors, which could occur in the sites of YRP, and identified correlations according to direct and indirect influences during the FED project. Multiple clients and differe nt domestic and overseas standards are related to the project. Besides, as the USFK is the end -user, the project showed the characteristics of overseas construction project. Complex conditio ns were to be considered. In this study, we have derived the following strategies of risk man agement.

The clients on the South Korean side should discuss design conditions with those on the US side in advance so that unreasonable demand of FED or the end-user for design change would not suspend or delay the construction. In addition, a sufficient construction period nee $\mathrm{ds}$ to be ensured beforehand in order to prevent urgent construction work or completion of $\mathrm{c}$ onstruction.

The clients on the US side should determine designs of bases and infrastructures like ele ctricity, waste water and Gas. Besides, the procedure of construction completion and delivery conditions should be clearly presented to the South Korean side. In this way, design changes or delay in construction due to quality issue need to be prevented.

Constructors and designers should make a perfect preparation beforehand in order to pre vent any delay in decision-making among many stakeholders including MURO, LH, FED and the end-user. The periods for bringing in and approving imported materials should be consid ered during preparation.

Construction project managers should establish the criteria and procedure of decision-mak ing in order to immediately settle any disagreement concerning design change or delivery. De signs need to be managed in accordance with the quality management standards provided by the US side.

YRP also implies fundamental problems that need to be proactively solved for avoiding $r$ isks. The construction is delayed also for security and other reasons presented by the clients on the US side. As the Mater plan (MP) has not been decided yet and continues to be modifi ed, LDUI (Land Development and Utility Infrastructure) within the site is interrupted, and th e commissioning schedule and adjacent works are seriously affected (F). Based on the overall program schedule, which was reversely calculated from the pronounced time of returning the US military bases (thus the construction period is $20 \sim 30 \%$ shorter than LPP), the construction work started anyway. However, bankruptcy of contractors, delay in design change, problems of procuring imported materials, and many other factors of delay have occurred in a complex way so that the schedule of completion can hardly be met (E). Moreover, as various DPWs participate at the completion stage of construction, design changes and quality defects may oc cur, which makes it more difficult to accommodate the planned schedule. Accordingly, from a s early as the construction stage, opinions need to be shared with DPW and necessary inform ation is to be provided periodically. In this way, the completion schedule of construction sho uld not be affected by any unreasonable design change during the completion stage (D).

In a future work, types of risk factors need to be classified according to characteristics of projects by using the structural equation modeling. This is to identify errors between a plann ed construction period and a completion period and between an estimated cost and a finally calculated cost. In addition, additional works seem to be necessary to adopt diverse approach es such as inputting various dependent variables or expanding parameters. Due to the domest ic situation, this study does not show any sufficient continuity with additional relocation proj ects of US military bases. However, this study has academic significance in analyzing the com petitiveness of domestic companies with respect to risk management in a large-scale national project, which includes various domestic and overseas companies as participants, and proposi ng practical strategies for risk management.

\section{References}


1. Kim, J. H. Military Facility Relocation Project Delay Analysis and Improvement Plans; With a Focus on Agreement and Contract Stage. Master's, Kyung Hee University, Korea, 2015.

2. Han, H. W. A study on the application of work performance management process for PM service according to USFK base relocation program. Master's, Chung Ang University, Korea, 2013.

3. Baloi, D. and Price, A. D. F. Modeling Global Risk Factors Affecting Construction Cost Performance. International Journal of Project Management, 2003, Vol. 21, pp. 261-269.

4. Bing, L. and Tiong, R. L. K. Risk Management Model for International Construction Joint Ventures. Journal of Construction Engineering and Management, 1999, Vol. 125, No. 5, pp. 377-384.

5. Chan, E. H. W. and Tse, R. Y. C. Cultural Consideration in International Construction Contracts. Journal of Construction Engineering and Management, 2003, Vol. 129, No. 4, pp. 375-381.

6. Han, S. H. and Diekmann, J. E. Approaches for Making Risk-Based Go/No-Go Decision for International Projects. Journal of Construction Engineering and Management, 2001, Vol. 127, No. 4, pp. 300-308.

7. Hastak, M. and Baim, E. J. Risk Factors Affecting Management and Maintenance Cost of Urban Infrastructure. Journal of Infrastructure Systems, 2001, Vol. 7, No. 2, pp. 67-76.

8. Mohamed S., Performance in International Construction Joint Ventures: Model Perspective. Journal of Construction Engineering and Management, 2003, Vol. 129, No. 6, pp. 619-626.

9. Pinto, J. K. and Mantel, S. J. Jr. The Causes of Project Failure, IEEE Transactions on Engineering Management, 1990, Vol. 37. No. 4, pp. 269-276.

10. Wang, S. Q.; Tiong, R. L. K., Ting, S. K. and Ashley, D. Evaluation and Management of Political Risks in China's Bot Projects. Journal of Construction Engineering and Management, 2000, Vol. 126, No. 3, pp. 242250.

11. Kim, J. H. An analysis of the changes in the cause-and-effect relationships between socio-economic indicators and the road network of Seoul using structural equation model. Journal of the Korean Geographical Society, 2009, Vol. 44, No. 6, pp. 797-812.

12. Lee, J. S.; Ahn, B. J. and Kim, J. J. Evaluating and Suggesting Key Risk Factors according to Risk Hierarchy of Occurrence Field in the Overseas Development Projects. Korean Journal of Construction Engineering and Management, 2013, Vol.13, No.2 pp. 70-79.

13. An, B. H.; Han, Kim, J. E. and Kim, Y. S. The Analysis of the Weights of Country Risk by Participants of Overseas Construction Projects. Korean Journal of Construction Engineering and Management, 2013, Vol.14 No.2 pp. 150-159.

14. Ko, O. Y. An analysis of the PM case and organization system for the program management performance model improvement; focus on the national mega project involved in the multinational corporations. Master's, Yonsei University, Korea, 2009.

15. Park, S. P. Research of Procedures and Management for F.E.D, USFK Base Relocation Construction. Master's, Myongji University, Korea, 2014.

16. Baek, M. C. The Method of Calculation Integrated Management Cost Estimate based on Project Activities (ICEP). Master's, Chungbuk National University, Korea, 2015.

17. Suk, K. W. An analysis on the characteristics of cost schedule integrated management by progress measurement methods. Master's, Sungkyunkwan University, Korea, 2013.

18. Lee, K. H. Assessment of Delays in the Military Facility Relocation Projects and Improvement Plan. Doctor's, Dongguk University at Korea, 2013.

19. Hwang. J. H. ; Ham, N. H.; Kim, J. H. and Kim, Jae-Jun. Analysis of the Construction Process Managed by the U.S. Army Corps of Engineers Far East District Using IDEF0. Journal of the Korean Institute of Building Construction. 2010, Vol.10 No.1, pp. 163-173.

20. Yang, J. B., and Ou, S. F. Using structural equation modeling to analyze relationships among key causes of delay in construction. Canadian Journal of Civil Engineering, 2008, Vol. 35, pp. 321-332.

21. Gang, S. B. A study on the effects of integrated project management maturity on the project performance; focus on overseas plant construction project. Doctor's, Hanyang University, Korea, 2016.

22. Lee, Y. W.; Lee, S. K.; Jang, W. S. and Han, S. H. Constructability Assessment Model for International Construction Projects Using Structural Equation. Journal of the Korean Society of Civil Engineers, 2015, Vol.35 No.4, pp. 941-951.

23. Lee, G. K. and Lee, J. H. A Study on the Solution of Unsold Houses through User Centered Marketing Strategies. Journal of the Korea Academia-Industrial cooperation Society, 2014, Vol.15 No.3, pp.1318-1326. 
24. Yoon, D. G.; Jeong, M. O. and Lee, S. Y. An Analysis on the Effect of U-City Service System on Residential satisfaction Level of Apartment Housing. Journal of the KAHPS, 2013, Vol.21 No.1, pp. 83-107.

25. Yoon, K. S.; Lee, Y. B. and Kim, S. H. A Study on the User Satisfaction of Records and Information Management System in Construction. Journal of the KBIBLIA. 2016, Vol.27 No.2, pp. 5-27.

26. Kim, H. J. and Lee, J. H. Analysis of impact structure on Business satisfaction and Continuous business intention by the conflict Response and processing of Apartment Reconstruction projects. Journal of the Korea Academia-Industrial cooperation Society, 2015, Vol. 16, No. 3 pp. 1699-1706,

27. Hwang, J. M. and Lee, J. H. An Analysis on the Effect of Environmental; Friendly Planning Elements on Residential satisfaction Level of the High - Rise Residential Complex. Journal of the Korea Content Association. 2014, Vol. 14, No. 3 pp. 438-450.

28. Heo. B. Y.; Song, J. W.; Yoon, S. U. and Lee, S. O. Estimation of Post Evaluation Index of Natural Disaster Prevention Projects using Structure Equation Modeling. Journal of the Korean Society of Civil Engineers, 2014, Vol. 34, No. 6 pp. 1807-1814.

29. Likert, R. The Human Organization: Its Management and Value. NY: Mc Graw-Hill, 1969.

30. Baccarini, D., and Archer, R. The risk ranking of projects: a methodology. International Journal of Project Management, 2001, Vol. 19, No. 3, pp. 139-145.

31. Pinto, J. K. and Mantel, S. J. Jr. The Causes of Project Failure. IEEE Transactions on Engineering Management, 1990, Vol. 37. No. 4, pp. 269-276

32. SPSS Inc. SPSS for Windows version 12.0. http://www.spss.com

33. Molenaar, K., Washington, S., and Diekmann, J. Structural equation modeling of construction contract dispute potential. Journal of Construction Engineering and Management, 2000, Vol. 126, No. 4, pp. $268-277$.

34. H. A. Linstone and M. Turoff. The Delphi Method: Techniques and Applications. Addison Wesley, 1975.

35. J. B. Yang and S. F. Ou Using structural equation modeling to analyze relationships among key causes fo delay in construction.Canada Journal of Civil and Engineering , 2008, Vol.35, pp. 321-332.

36. Wang, P. S. P., and Cheung, S. O. Structural equation modeling of trust and partnering success. Journal of Management in Engineering, 2005, Vol. 21, No. 2, pp. 70-80.

37. Baumgartner, H., and Homburg, C. Applications of structural equation modeling in marketing and consumer research : a review., International Journal of Research in Marketing, 1996, Vol. 13, No. 2, pp. 139161.

38. Ashley, D. B., and Bonner, J. J. Political Risks in International Construction. Journal of Construction Engineering and Management, 1987, Vol. 113, No. 3, pp. 447-467.

39. Construction Economy Research Institute of Korea (CERIK). Global Engineering-Construction Strategies for Korean Construction Companies, CERIK Research Report, 2008-08.

40. Byrne, B. M. Structural equation modeling with EQS and EQS/Window: basic concept, applications a nd programming. Sage Publications, Thousand Oaks, Calif. 1994. 